\title{
Aikuiskasvatuksesta todellisuuden hallinnan välineiden kehittämiseen
}

Suomalaisessa yhteiskunnassa tapahtui 1960-70 -luvuilla ennennäkemättömän raju elämäntavan ja kulttuurin muutos. Suuri osa väestöä siirtyi uuteen elinkeinoon ja elämänympäristöön. Sekä maaseudun että teollisuusyhdyskuntien perinteinen elämänmeno muuttui syvällisesti. Työn muutoksen myötä monet muidenkin elämänalueiden vanhat toiminta-ja ajattelumallit kävivät mahdottomiksi tai menettivät aikaisemman merkityksensä. Ihmiset joutuivat keksimään uusia tapoja ratkaista elämän käytännöllisiä ja henkisiä ongelmia.

En tiedä onko kukaan tutkinut, missä määrin aikuiskoulutus ja vapaa sivistystyö kykenivät 1960-70 -lukujen muutoksessa auttamaan ihmisiä uuden elämäntavan rakentamisessa. Varmaan eivät siinä määrin kuin olisi ollut tarpeen. Yhteiskunnallinen murros ja sen luomat ongelmat ovat tulevaisuudessa tuskin pienempiä kuin ne olivat takavuosina. Siksi on syytä kysyä onko aikuiskasvatustoiminta nyt paremmin muutoksen tasalla kuin aikaisemmin?

Viime vuoden aikana aikuiskasvatuksen tulevaisuutta koskeva julkinen keskustelu - joka oli hämmästyttävän vaimeata - keskittyi kahteen kysymykseen: aikuiskoulutuksen hallinnollisten puitteiden uudistamiseen ja siihen, miten aikuiskasvatustyössä tulisi ottaa huomioon tekninen kehitys ja työssä tapahtuvat muutokset.

Aikuiskoulutuksen hallinnon kehittämisessä ollaan laajalti samaa mieltä siitä, että aikuiskoulutusta on laajennettava ja työelämän koulutusta on lisättävä. Mutta siitä, mitkä tehtävät tuon lisätyn aikuiskasvatuksen tulisi täyttää, ei paljon puhuta. Yleisesti viitataan tietotekniikkaan ja muun uuden tekniikan luomiin koulutustarpeisiin, mutta varsin vähän on analysoitu, millä eri tavoin uutta tekniikkaa voidaan käyttää ja millaisia muutoksia työelämässä se mahdollistaa. Yleisesti tunnutaan ajattelevan, että aikuiskoulutuksen kehittämisen ongelmat ovat ensisijassa taloudellisia ja organisatorisia. Sen enempää ammatillisen koulutuksen kuin vapaan sivistystyönkään toimintatapoihin ei katsota tarvittavan syvällisiä muutoksia.

Työelämän ja elämäntavan kehitystä koskevassa keskustelussa esitetään, että tekninen kehitys lisää vapaa-aikaa, aiheuttaa työttömyyttä ja jakaa väestön jyrkästi koulutettuun eliittiin ja työelämästä syrjäytyvään vähänkoulutettujen joukkoon jne. Näistä toteamuksista tehdään toistuvasti samat käytännön johtopäätökset:

- ammatillisen aikuiskoulutuksen on edistettävä uuden tekniikan käyt- 
töönottoa ja ammattirakenteen muutosta

- ammatillisen aikuiskoulutuksen on autettava työelämästä syrjäytyneitä palaamaan työhön

- vapaan sivistystyön tulee tarjota lisääntyvän vapaa-ajan käytössä vaihtoehto ylikansalliselle massakulttuurille ja passiiviselle kulutukselle, tai niin kuin TASKU mietinnössään asian ilmaisee: "tarjota ihmisille kasvattavaa, avartavaa ja virkistävää "puuhaa" näiden palvelujen avulla"'

- vapaan sivistystyön on tarjottava yksilölle mahdollisuuksia toteuttaa itseään ja olla oman toimintansa subjekti vastapainoksi tiukasti ohjelmoidulle työelämälle jne.

Mutta sitä, mihin arviot perustuvat, mistä muutoksissa pohjimmiltaan on kysymys ja miten ne voitaisiin hallita, ei enää jaksetakaan pohtia. Analyysin syvenemisen ja merkittävien uusien näkemysten syntymisen sijasta aikuiskoulutuksen tulevaisuutta koskeneelle julkiselle keskustelulle on ollut ominaista ylimalkaisuus ja pinnallisuus.

Tarkoitukseni ei ole vähätellä työelämään ja koko yhteiskunnan muuttumiseen liittyviä vakavia ongelmia ja niiden aikuiskasvatustyölle asettamia suuria haasteita. Päinvastoin, teesini on, että aikuiskasvatuksen tulevia ongelmia ei voida ymmärtää eikä niille voida löytää ratkaisuja analysoimatta huomattavasti tähänastista konkreettisemmin työelämässä ja ihmisten yhteiskunnallisessa toiminnassa jo nyt tapahtumassa olevia laadullisia muutoksia sekä niihin sisältyviä ongelmia ja kehitysmahdollisuuksia. Ratkaisuja ei myöskään voida löytää, jos ongelmia ja niiden ratkaisuvaihtoehtoja tarkastellaan vain aikuiskoulutuksen vallitsevien toimintatapojen pohjalta. Muutoksia ei nimittäin tapahdu vain työn, vapaa-ajan, ammattiopetuksen ja sivistystyön määräsuhteissa ja sisällöissä vaan myös niiden keskinäisissä suhteissa ja luonteessa. On paljon puhuttu perinteisten instituutioiden ja työmuotojen asemasta, aikuiskoulutukseen osallistumisen muodollisista esteistä tai aikuiskasvatuksen eri muodoille sopivista nimityksistä. Nyt tulisi tutkia sitä, millaisia ovat "aikuisten kasvamisen" konkreettiset sisällölliset ongelmat ja edellytykset tämän päivän ja huomisen Suomessa.

Mistä sitten johtuu aikuiskasvatuksen tulevaisuutta koskevan keskustelun hedelmättömyys. Yksi syy siihen on tyytyminen arkiajattelun ja karkeiden tilastotietojen antamaan kuvaan. Toinen syy on kysymyksenasetteluja harhaan johtavissa, vanhentuneissa käsitteissä (en tässä tarkoita terminologiaa, vaan termien takana olevien käsitysten ja ideoiden kokonaisuuksia) sekä niihin perustuvassa asioiden virheellisessä lokeroimisessa. Erityisesti tämä koskee ammatillisen ja muun sivistyksen välistä rajanvetoa sekä työn ja vapaa-ajan vastakkainasettelua.

Zachris Castrénista lähtien suomalaisessa aikuiskasvatuksessa on asetettu jyrkästi vastakkain ammatillinen sivistys ja yhteiskunnalliseen ja "'kulttuuritoimintaan"' liittyvä vapaa sivistystyö. Tähän jaotteluun näyttää liittyvän tulkinta, jonka mukaan ammattisivistys edustaa yksilön kannalta 
ulkoa ohjattua valmiin tiedon omaksumista. Vapaassa sivistystyössä taas on kysymys yksilön asettumisesta elämänsä aktiiviseksi subjektiksi ja hänen mahdollisuuksistaan kehittää persoonallisuuttaan omista lähtökohdistaan. Ammatillisen sivistyksen sisällön määrittelyssä olennaista on tietojen ja taitojen välinearvo. Vapaan sivistystyön sen sijaan tulisi olla itseilmaisun, luovuuden ja tiedon itsearvoisen harrastamisen valtakunta, johon tiedon välinearvon pohtiminen ei kuulu.

Tämä dualismi johtaa siihen, että sen enempää ammatillinen aikuiskasvatus kuin vapaa sivistystyökään eivät kykene täyttämään ajankohtaisia tehtäviään. Edellisessä päädytään epärealistisen suppeaan näkemykseen työstä ja sen hallinnan perusteista, jälkimmäisessä nähdään kulttuuri virheellisen rajoittuneesti. Eikö juuri työ ole ihmisen luovuuden tärkein foorumi? Eikö työtoiminnan hallinta edellytä paljon sellaistakin, mikä ei kuulu kapeasti ymmärretyn ammattisivistyksen piiriin? Entä mitä on sellainen persoonallisuuden ja luovuuden kehittyminen, joka ei sisällä uusien ajattelun ja toiminnan välineiden omaksumista ja kehittämistä.

Työn ja tekniikan kehityksen keskeisin piirre tällä hetkellä on tuotannon ja hallinnon automatisointi, ihmisen aikaisemmin suorittamien rutiinimaisten tiedonkäsittelytehtävien siirtäminen koneelle. Toisin kuin usein esitetään, tässä kehityksessä ei ole kysymys ihmisen korvaamisesta koneella, vaan siitä, että työvälineenä on entistä täydellisempi, laajempi ja tehokkaampi tekninen järjestelmä. Työ ei voi kehittyä tekijöistään riippumatta. Uuden tekniikan käyttöönotto ei merkitse vain uusien laitteiden ostamista, vaan monitahoista oppimisprosessia uusien toimivien työmuotojen löytämiseksi ja entistä laajemman kokonaisuuden hallitsemiseksi.

Teknisten uudistusten toteuttamisessa vaikuttaa aina monia keskenään ristiriitaisia tarpeita ja pyrkimyksiä. Toiminnan häiriöttömän kulun ja tuotteiden laadun varmistamiseksi henkilöstön tulisi olla hyvin koulutettua ja osallistutettua välineistön kehittämiseen. Häiriöiden vähenemisen ja tuotteiden paremman laadun tuomien etujen vastapainona ovat tällöin kuitenkin suuremmat koulutuskustannukset. Lyhyen tähtäyksen taloudelliset paineet edellyttäisivät koulutuskustannusten minimoimista erottamalla suunnittelu ja toteutus jyrkästi toisistaan. Työn organisoinnissa on löydettävä jokin tapa ratkaista erilaisten vaatimusten ristiriita. Työntekijöiden aktiivisuus vaikuttaa siihen, millaiseksi lopputulos muodostuu. Sillä taas, miten uusien välineiden käyttöä organisoidaan, on laajoja heijastusvaikutuksia työntekijöiden myöhempään elämäntapaan ja kehittymiseen.

Työhön liittyvä opiskelu ei ole aina valmiin tiedon ulkoa ohjattua omaksumista, jonka merkitys yksilön luovan henkisen kehityksen kannalta olisi toisarvoinen eikä vapaa-aika yksilön toimimista aktiivisena, luovana subjektina. Nouseminen oman toimintansa subjektiksi yhdellä elämänalueella auttaa elämän tietoista hallintaa myös muilla alueilla. Aikuiskasvatuksessa on kysymys monitahoisista kehitysprosesseista, joissa ihmisen toiminnan eri osa-alueet vaikuttavat toisiinsa. Työtoiminta on kuitenkin koko elämäntavan kehityksen kannalta ydinalue. 
Ammattisivistyksen ja vapaan sivistystyön jyrkkä käsitteellinen erottaminen toisistaan johtaa helposti myös kapeaan ja yksipuoliseen tulkintaan kulttuurista. Kulttuurin tuotteita ei tarkastella ihmisen käytännöllisten, älyllisten ja moraalisten ongelmien ratkaiseminen apuneuvoina, toiminnan välineinä, vaan "omaehtoisena harrastamisen"' (hobby) kohteina. Kulttuurin tutkijoilla on aivan toinen käsitys siitä, mitä kulttuuri on. Kulttuuriantropologian klassikko Bronislaw Malinowski korostaa erityisesti kulttuurin instrumentaalista luonnetta. Erik Ahlman määrittelee kulttuurin ihmisyhteisön tietoiseksi toiminnaksi, jolla todellisuutta muutetaan toiseksi kuin se "luonnostaan"' on. Jos kulttuuri ymmärretään näin, on kysyttävä, millä välineillä todellisuuden muuttaminen voidaan toteuttaa. Ihmisen tietoisesti tuottamat tekniset välineet, kommunikaatiovälineet (kieli) ja ajatusvälineet (käsitteet) ovatkin Ahlmannin mukaan keskeinen osa kulttuuria. Välineiden kehittyminen ja kulttuurin kehittyminen liittyvät kiinteästi toisiinsa. Pyrkiessään muuttamaan todellisuutta ihmiset joutuvat koettelemaan sekä todellisuutta että välineidensä pätevyyttä. Jos välineet eivät riitä, on kyettävä luomaan uusia, parempia välineitä ymmärtää ja muuttaa todellisuutta.

Välineiden kehittämisen tarve on ilmeisintä työtoiminnassa. Siksi on luonnollista, että tähän puoleen kulttuurista on kiinnitetty huomiota juuri työn tutkimisen ja kehittämisen yhteydessä. Kehittävä työntutkimus, jota pääosa tämän numeron artikkeleista käsittelee, tarkastelee "'aikuiskasvatusta"' juuri todellisuuden ymmärtämisen ja hallinnan välineiden kehittämisenä. Aikuiskasvatuksen näkökulmasta työtä voidaan pitää ikäänkuin määrätietoisen toiminnan prototyyppinä. Kuten yllä on pyritty osoittamaan, kaikessa kulttuurin kehittämisessä on kysymys toiminnan välineiden kehittämisestä. Myös vapaan sivistystyön piirissä on tarpeen kysyä, missä määrin on kyetty kehittämään entistä parempia todellisuuden ymmärtämisen ja siihen vaikuttamisen välineitä.

Huomion suuntaaminen ihmisten toimintaan ja toiminnan kehittämiseen edellyttää aikuiskasvatukselta kïnteää yhteyttä käytäntöön, siihen toimintaan, jonka välineiden kehittämiseen osallistutaan. Uusien välineiden kehittäminen ei ole kuitenkaan vain opiskelun asia, se vaatii tutkimusta, suunnittelua ja uusien ratkaisujen aktiivista etsimistä ja kokeilua. Perinteisen aikuiskasvatuksen suuri puute on siinä, ettei se ole katsonut välineiden kehittelyä osaksi kasvatusprosessia. On ajateltu, että ne on jo valmiiksi jossain muualla kehitetty. Kuitenkin valmiidenkin välineiden aito omaksuminen edellyttää aina välineen osittaista uudelleenluomista ja kehittelyä. Jotta välineiden ja kulttuurin kehittämisen osatehtävät saataisiin kiinteään vuorovaikutukseen keskenään myös aikuiskasvatustoiminnassa tarvitaan uusia ajattelun ja toiminnan välineitä sekä uusia yhteistoimintamuotoja.

Tämä Aikuiskasvatuslehden numero keskittyy työelämän koulutuksen kysymyksiin. Numeron artikkeleilla on yksi yhteinen lähtökohta: työn ja teknisen kehityksen toteuttamisessa on olemassa monia vaihtoehtoja. Siksi 
aikuiskoulutus ei voi olla ennakoidun kehityksen passiivista seuraamista. Sen tulisi kehittyä työtoiminnan konkreettisten kehitysmahdollisuuksien tutkimiseksi ja näiden kehitysmahdollisuuksien realisoimiseksi yhteistoiminnassa työntekijöiden kanssa, kehittäväksi työn tutkimukseksi.

Reijo Miettinen on osallistunut aktiivisesti Valtion koulutuskeskuksen toteuttaman henkilöstökouluttajien jatkokoulutusohjelman opetukseen. Hän kuvaa artikkelissaan ''Kognitiivisesta kurssididaktiikasta kehittävään työntutkimukseen' jatkokoulutusohjelmassa välitettyjen työelämän koulutustyön välineiden kehittymistä, koulutusta koskevan teoreettisen ajattelun muuttumista kurssikeskeisestä työtoimintakeskeiseksi.

Yrjö Engeström kuvaa artikkelissaan 'Kehittävän työntutkimuksen peruskäsitteitä"' kehittävän työntutkimuksen lähtökohtia ja metodisia periaatteita sitä, millaisia analyyseja ja työvälineitä tarvitaan toiminnan kehitysmahdollisuuksien löytämiseksi ja uusien henkisten ja käytännöllisten työvälineiden kehittämiseksi.

Kari Toikan, Raimo Hyötyläisen ja Leena Norroksen artikkeli '’Työn kehitys joustavassa valmistuksessa" kuvaa metallin työstöön liittyvän uuden tekniikan käytössä ilmenevää kahta erilaista strategiaa, joista toinen pyrkii korvaamaan ja toinen kehittämään ihmistyötä. Artikkelissa osoitetaan perinteisen työn tutkimuksen riittämättömyys silloin, kun uuden tekniikan käyttöönotossa sovelletaan kehittävää strategiaa.

Robert Arnkilin artikkelissa 'Kehittävät tehtävät koulutus- ja tutkimusmenetelmänä ammatinvalinnanohjaustyössä" kuvataan kehittävän työntutkimuksen soveltamista ammatinvalinnanohjaajien työn tutkimiseen ja kehittämiseen. Artikkeli tuo esiin sen, miten kehittävä työntutkimus on samanaikaisesti sekä koulutusta että tutkimusta. Artikkelissa käsitellään kehittävien tehtävien käyttöä välineinä, joilla pyritään samanaikaisesti sekä työn hallinnan kehittämiseen että uusia mahdollisuuksia koskevan tiedon hankintaan.

Pentti Vuorisen artikkelissa "'Tekninen muutos, määrällinen koulutustarve ja aikuiskoulutus" tarkastellaan mikroelektroniikkaa syvällisenä teknisen paradigman muutoksena. Muutoksen vaikutukset ovat niin monitahoisia, että perinteinen koulutussuunnittelu ei riitä niiden hallitsemiseen. Uutta tekniikkaa voidaan soveltaa monella eri tavalla riippuen siitä, mihin suuntaan tekniikkaa hyväksi käyttävää toimintaa halutaan kehittää. Koulutuksen suunnittelemiseksi tarvittaisiin konkreettisia analyyseja eri toimialojen, ammattiryhmien ja alueiden kehitysongelmista ja vaihtoehdoista. Kun kysymys on uuden teknologian edellyttämästä koulutuksesta, nuorisoasteen koulutusta ja aikuiskoulutusta tulisi tarkastella yhtenä kokonaisuutena.

Jaakko Virkkunen 